\title{
Effectiveness of Red Guava Juice in Increasing Erythrocyte Index for Prevention of Anemia in Adolescents
}

\author{
$1^{\text {st }}$ Hardimarta FP \\ Immunology \\ Akademi Analis Kesehatan 17 Agustus 1945 \\ Semarang, Indonesia \\ sisca_hardi@ymail.com
}

\author{
$2^{\text {nd }}$ Yuniarti CA \\ Hematology \\ Akademi Analis Kesehatan 17 Agustus 1945 \\ Semarang, Indonesia \\ christinaarie@yahoo.com
}

\author{
$3^{\text {rd }}$ Aini MN \\ Hematology \\ Akademi Analis Kesehatan 17 Agustus 1945 \\ Semarang, Indonesia \\ melinda.nuraini@gmail.com
}

\begin{abstract}
The aim of study is to determine the effect of red guava juice on the erythrocyte index profile of adolescent. Method of research is pre experimental with one group pretest postest design. 30 students at AAK 17 August 1945 Semarang were selected by purposive sampling technique. Guava juice are given 3 $\mathrm{cc} / \mathrm{kg} / \mathrm{day}$ for 7 days. Erythrocyte index were measured at before and after treatment. There was a significant differences between pre test and post test. Moreover consumption of red guava juice is more effective in increasing erythrocyte index. Red Guava juice can be a supplementary to prevent occurence of anemia in adolescents.
\end{abstract}

Keywords-red guava, erythrocyte index, anemia, adolescent

\section{INTRODUCTION}

Anemia is one of the nutritional problems still occurring in Indonesia, mainly caused by iron deficiency. Iron deficiency anemia has a great influence on adolescence and premenopausal women in developing countries and poor countries. The prevalence of adolescent anemia is $27 \%$ in developing countries and $6 \%$ in developed countries. The prevalence of iron anemia without the addition of reported dietary diets is $40 \%$ in preschool children, $30 \%$ in teens and women of childbearing age, and $38 \%$ in pregnant women. This shows an increase in physiological needs during a specific life phase and depends on sex, and the rapid growth phase in adolescence is a critical period [1, 3].

Adolescence is a growth and development period of physically, mentally and activities so that the needs of foods containing nutrients become larger. Young women have a higher risk of anemia due to increased iron demand due to growth and menstrual cycle. The amount of iron loss during a menstrual cycle of approximately $0.56 \mathrm{mg}$ per day is accompanied by a basal loss of $0.8 \mathrm{mg} /$ day so that the total amount of iron lost is $1.36 \mathrm{mg}$ per day $[4,5]$.
The diagnosis of iron deficiency anemia can be done by examining the erythrocyte index. The erythrocyte index examination consisted of 3 parameters are Mean Corpuscular Value (MCV), Mean Corpuscular Hemoglobin $(\mathrm{MCH})$, and Mean Corpuscular Hemoglobin Concertration (MCHC). A person with anemia will experience a decrease in $\mathrm{MCH}$ and $\mathrm{MCHC}$ levels, but the MCHC start decrease if the anemia has been long periode or severe. The degree of change in erythrocyte index level is related to the stage and duration of anemia.

During this time most people with anemia get iron intake through consumption of Fe tablets. However, many refuse to consume $\mathrm{Fe}$ tablet because of side effects are nausea,vomit and blackish-colored stool. Therefore needed another effort, one of them by consumption of red guava fruit (Psidium Guajava L) [6, 7]. Red guava fruit contains iron, vitamin $\mathrm{C}$, amino acids (tryptophan, lysine), calcium, phosphorus, sulfur, vitamin $\mathrm{A}$, and vitamin $\mathrm{B} 1$ [8]. Vitamin $C$ will increase the absorption of non heme iron up to four times or $2 \%-20 \%$. Red guava also contain antioxidant compounds are flavonoids and carotenoids such as beta carotene, lycopene, beta cryptoxanthin and polyphenols [9, 10]. Flavonoids help in preventing the adverse effects of free radicals. The erythrocyte membrane is one of the cell membranes susceptible to free radical attack. When free radicals attack the erythrocyte membrane, the fluidity of the cell membrane will be disrupted and cause lysis and even cell death, causing a decrease in the amount of erythrocytes and hemoglobin levels [11]. As an antioxidant, $\beta$ carotene works to capture free radicals, especially peroxyl radicals and hydroxyl and $\beta$-carotene works synergistically with vitamins $\mathrm{C}$ and $\mathrm{E}$ [12 ].

Features fruit guava having various types of antioxidant and potent antioxidant activity is great, researchers are interested to examine the effect of red guava juice against erytrocyte index on adolescent. 


\section{MATERIALS AND METHOD}

Method of research is pre experimental research with Pre and Post Design. This research was conducted at Medical Laboratory of Akademi Analis Kesehatan 17 August 1945 Semarang. Population are students at 3 grades at Akademi Analis Kesehatan 17 August 1945 Semarang. Sampling was taken in a total 30 respondents with sampling technique by purposive sampling, and criteria used as a sample respondents are girls students, not having menstruation as long as research, not being taking additional vitamins or supplement,not having chronic illnes, diets on balance nutrition. All the participants provided informed consent.

\section{A. Making Red Guava Juice}

The initial stage is done by collecting raw guava materials. Then the red guava fruit peeled, cut and separated with the seed of the fruit. Red guava juice is made by taking the essence of the flesh without seed is clean and fresh, then put in a blender without the addition of water or any other material

\section{B. Treatment}

Each respondent was given $100 \%$ guava juice with volume $3 \mathrm{ml} / \mathrm{kg}$ BW consumed 1 times / day for 7 days.

\section{Measurement of Hemoglobin}

Measurement of Hemoglobin content using Cyanmethemoglobin method using Drabkin's solution. The first tube contains $5 \mathrm{ml}$ of drabkin solution, a second tube containing $5 \mathrm{ml}$ of drabkin solution and $20 \mu \mathrm{l}$ of EDTA blood. Incubate at room temperature for \pm 5 minutes. Then read using Clinicon 4010 Photometer with $\mathrm{C} / \mathrm{F}$ program, $546 \mathrm{~nm}$ length and 36.77 factor.

\section{Measurement of Hematocrit}

Measurement of Hematocrit content using Mikromhematokrit method. Blood is inserted into a 3/4 hematocrit tube of the tube. Closes with putty. Centrifuge for 5 minutes with a speed of $16,000 \mathrm{rpm}$. The reading uses a hematocrit device.

\section{E. Measurement of Eritrocytes}

Sucking up EDTA blood until the line is 0.5. Dilute it with Hayem solution until line 101. Homogenize by turning the erythrocyte eyedropper pipette for 15-30 seconds (if not checked immediately put it horizontally). Dripped on the booth count Improved Neubauer and counted on 25 small squares.

\section{F. Measurements of Index Eritrocytes}

Mean Corpuscular Value (MCV)

$$
M C V=\frac{\text { Hematokrit }}{\text { Eritrosit }} \times 10(\mathrm{fl})
$$

Normal Values : 82 - 92 fl

Mean Corpuscular Hemoglobin (MCH)

$$
M C H=\frac{\text { Hemoglobin }}{\text { Eritrosit }} \times 10(\mathrm{pg})
$$

Normal Values : 27 - 31 pg

Mean Corpuscular Hemoglobin Consentration (MCHC)

$$
\text { MCHC }=\frac{\text { Hemoglobin }}{\text { Hematokrit }} \times 100(\%)
$$

Normal Values : $32-37 \%$

Data were analyzed by statistical test using computerized. Distribution data are normal so that the parametric statistic test was tested by Paired t-test. Data that is not normally distributed is tested by the Wilcoxon test. $95 \%$ confidence level or $\alpha=0.05$.

\section{RESULTS AND DISCUSSION}

Measurements conducted before and 7 days after guava juice juice red. Table 1 shows the average of MCV before the consumption of red guava juice was $84.83 \mathrm{fl}$ and after the consumption of red guava juice was $85.65 \mathrm{fl}$ with an increase of $0.97 \%$. The average $\mathrm{MCH}$ before the consumption of red guava juice was $28.37 \mathrm{pg}$ and after consumption of red guava juice was 29.81 with an increase of $5.07 \%$. The average of MCHC before the consumption of red guava juice was $33.44 \%$ and after consumption of red guava juice was $34.73 \%$ with an increase of $3.99 \%$.

\section{TABLE 1. MEAN OF ERYTHROCYTE INDEX}

\begin{tabular}{ccc}
\hline Variable & Pre Test & Post Test \\
\hline MCV (fl) & 84,83 & 85,65 \\
MCH (pg) & 28,37 & 29,81 \\
MCHC (\%) & 33,44 & 34,73 \\
\hline
\end{tabular}

Statistical Analysis results in the table. 2 obtained $\mathrm{P}=$ $0,000(\mathrm{P}<0.05)$ showned that the erythrocyte index after consumption of red guava juice increased significantly compared with before the consumption of red guava juice.

\begin{tabular}{lll}
\multirow{2}{*}{ TABLE 2. STATISTICAL ANALYSIS OF ERYTHROCYTE INDEX } \\
\hline & Normality Test & Statistical Analysis \\
\cline { 2 - 3 } & Sig. & Sig. \\
\hline MCV pretest & 0,005 & 0,000 (Wilcoxon) \\
MCV posttest & 0,011 & 0,000 (Paired T-Test) \\
\hline MCH pretest & 0,534 & 0,000 (Paired T-Test) \\
MCH posttest & 0,765 & 0,967 \\
\hline MCHC pretest & 0,240 & \\
MCHC posttest & 0, \\
\hline
\end{tabular}

This research proves that red guava juice has the potential to increase the value of erythrocyte index. The value of erythrocyte index after consuming guava juice increased compared to before consuming guava juice. This is due to the content in red guava fruit such as iron, vitamin C, amino acids (tryptophan, lysine), calcium, phosphorus, sulfur, vitamin A and vitamin B1 [8]. Red guava contains vitamin $\mathrm{C}$ two to four times higher than oranges so it can help the absorption of iron [6, 7]. In addition, vitamin $\mathrm{C}$ will also help increase the absorption of non heme iron by up to fourfold [13]. Red guava fruit also contains of amino acids, where amino acids and vitamin $\mathrm{C}$ will help the process of reduction of the ferrite form $(\mathrm{Fe}+++)$ to fero $(\mathrm{Fe}++)$ so that iron is easily 
absorbed. Vitamin $\mathrm{C}$ will also help remove iron from transferrin in the plasma in order to join into ferritin tissue.

The dietary needs of young women in the day for protein is 48-62 g, 19-26 mg of iron, vitamin B6 $1.25 \mathrm{mg}$ and vitamin $\mathrm{C} 60 \mathrm{mg}$. $\mathrm{Fe}$ is an essential ingredient in the formation of hemoglobin. Healthy human body contains \pm $3.5 \mathrm{~g} \mathrm{Fe}$ are almost entirely in the form of complex bonds with proteins. Approximately $70 \% \mathrm{Fe}$ in the body is functional and $30 \% \mathrm{Fe}$ rest is nonessential. $\mathrm{Fe}$ functional/essential is present in $\pm 66 \%$ of hemoglobin, myoglobin $3 \%$, an enzyme that serves to transfer electrons (sitokromoksidase, succinyl dehydrogenase, xanthine oxidase) as much as $0.5 \%$ and $0.1 \%$ transferrin. Iron nonessential there as a backup in the form of ferritin and hemosiderin as much as $25 \%$ and in the parenchymal tissue of approximately 5\%. parenchymal tissue of approximately $5 \%$. Iron that has been absorbed in the form of ferrous ions will be converted into a ferry in the mucosal cells which will then be entered into with intermediaries plasma transferrin, ferritin will then be converted into and stored in the intestinal mucosa. vitamin B6 along with the enzyme Aminolevulenat change Succinyl-CoA synthase and glycine into aminolevulenat acid (ALA). Furthermore, ALA will be condensed by ALA dehydratase enzyme to form two molecules of water and one molecule of porphobilinogen. This porphobilinogen be synthesized to be protoporphyrin III. The involvement of iron in hemoglobin synthesis process is in the final stages of heme formation, where the merger of ferrous iron into protoporphyrin III catalyzed by the enzyme ferroketalase [14].

Any increase in frequency of vitamin $\mathrm{C}$ consumption once (100 grams of red guava) will increase the hemoglobin level by $0.06 \mathrm{~g} / \mathrm{dl}$. This is in line with other researchers' claims that vitamin $\mathrm{C}$ increases the absorption of iron non heme by four times more than those who do not consume vitamin C. So it has a positive relationship where there is a higher tendency of iron consumption higher $\mathrm{Hb}$ level (each addition of $1 \mathrm{mg}$ of iron consumption of $\mathrm{Hb}$ added $0.0365 \mathrm{~g} / \mathrm{dL}$ ). Vitamin $\mathrm{C}$ can increase the acidity so it can help the absorption of iron in the stomach. This vitamin $\mathrm{C}$ can increase iron absorption by $30 \%$. In red guava fruit contains compounds that can increase hemoglobin levels in the blood, among others: iron, vitamin C, vitamin A, copper and phosphorus [15].

Red guava also contains antioxidants such as flavonoid compounds, a combination of saponins with oleanolic acid, guaijavarin, and quercetin [16]. The activity of these antioxidant compounds can be affected by the level of maturity, part of fruit, and the varity of guava. Mature red guava has higher antioxidant activity compared to perfectly immature fruit. In addition, fruit flesh with seeds have higher antioxidant activity than fruitless fruits. Antioxidant compounds in red guava also affect the erythrocytes, one of which is flavonoids. Flavonoids are compounds of phytochemicals that are divided into several classes such as flavones, flavonols, flavanones, and isoflavones. Flavonoids help in preventing the adverse effects of free radicals. Flavonoid compounds react directly with free radicals, where unpaired electrons in free radicals are captured by flavonoids without producing other free radicals as a result of the reaction. The erythrocyte membrane is one of the cell membranes susceptible to free radical attack. If free radicals attack the erythrocyte membrane, the fluidity of the cell membrane will be disrupted which can cause lysis and even cell death so that there will be changes in the amount of erythrocytes and hemoglobin levels. This results in a decrease in the number of erythrocytes. Therefore, by consuming red guava juice containing flavonoids can affect the increase in the number of erythrocytes and hemoglobin $[11,17]$.

Guava juice with sufficient doses can improve iron reserves in the body. Improvement of iron reserves will increase the formation of Hemoglobin levels, but it can also be through the transport of iron by blood transferrin to be brought to the bone marrow and other body parts which then iron will be used to form hemoglobin in the spinal cord. Bone marrow also requires precursors such as iron, vitamin C, vitamin B12, cobalt and hormones for the formation of red blood cells and hemoglobin so as to increase the amount of erythrocytes and hematocrit levels. Therefore, with red guava juice is expected to improve the erythrocyte index and reduce the incidence of anemia, especially iron deficiency anemia in adolescent women.

\section{CONCLUSION}

The consumption of red guava juice can improve the erythrocyte index an prevent anemia in adolescent girls.

\section{ACKNOWLEDGEMENTS}

We thank the participants for their continuous support with interest for the study. The author is very thankful to the authorities of Akademi Analis Kesehatan 17 Agustus 1945 Semarang for granting the permission to carry out the study.

\section{REFERENCES}

[1] Faris NS, "Prevalence of iron deficiency anemia aethological and prevention", European Journal of Biology and Medical Science Research. Vol.2. No. 22, 2014, p : $55-60$.

[2] Stevens GA, Finucane MM, De-Regil LM, et al, "Global, regional, and national trends in haemoglobin concentration and prevalence of total and severe anaemia in children and pregnant and non-pregnant women for 1995-2011: a systematic analysis of population-representative data", Lancet Global Health, 2013; 1(1): e16-e25.

[3] Pasricha SR, Drakesmith H, Black J, Hipgrave D, Biggs BA, "Control of iron deficiency anemia in low- and middle- income countries. Blood", 2013; 121: 2607-17

[4] Indartanti D, Kartini A, "The correlation between nutrition status and anemia on girls teenager", Journal of Nutrition College. Volume 3( 2), 2014, p : 33 - 9

[5] Warrilow G, Kirkham C, Ismail KMK, Wyatt K, Dimmock P, O'Brien S, "Quantification of Menstrual Blood Loss [Review] ", Obstet and Gynecol, 2004: vol.6.p.88-9.

[6] Sulistyowati, "The influence of red guava to haemoglobin level on periods among STIKES Muhammadiyah Lamongan students", Jurnal Kebidanan dan Keperawatan. 2015, 11(2), pp.135-142.

[7] Kumar,A, "Importance for life 'psidium guava'. international journal of research in pharmaceutical and biomedical sciences", 2012, Vol. 3 (1). 137-143

[8] Helmi, A. Agustina and Rizal, Z, "The effect of red guava juice to eritrocyte, haemoglobin, and trombocyte level to the white mice", Journal of Science and Technology of Pharmacy, 2013, 18(1), pp.43-48.

[9] Oliveira D S, Lobato AL, Ribeiro SM, Santana AM, Chaves JB, "Carotenoids and vitamin $\mathrm{c}$ during handling and distribution of 
guava (psidium guajava 1.), mango (mangifera indica 1.), and papaya (carica papaya 1.) at commercial restaurants", J. Agric Food Chem, 2010, 58: 6166-6172

[10] Ordonez-Santos LE, Vazquez-Riascos A, "Effect of processing and storage time on the vitamin $\mathrm{C}$ and lycopene contents of nectar of pink guava (Psidium guajava L)", Arch Latinoam Nutr.60: 280284, 2010.

[11] Sulastri, D. \& Keswani, R.R, "Effect of isoflavonoid toeritrocyte and catalase enzyme", Medical Magazine of Andalas Vol 33 No. , 2009.

[12] Silalahi, J, "Functional food", Yokyakarta: Kanisius, 2006, pp. 38-56

[13] Argana, G. Kusharisupeni and Utari, D.M, "Vitamin C as dominant factor to haemoglobin level in women", Medical Journal of Trisakti. 23(1), 2004, pp.6-14.
[14] Purwaningrum Y, "Effects of mixed green beans essences and red guava of haemaglobin levels in young women ages $13-16$ years old", International Journal of Scientific and Technology Research. Volume 7. (1), 2018, p. $75-9$

[15] Sambou, C.N. Yamlean, P.V.Y. and Lolo, W.A, "Effectivity test of red guava to haemoglobin level among white mice", Journal of Pharmacy 3(3), 2014, pp.220-224.

[16] Paniandy,JC, Chane Ming, J, and Prestibatesti, J.C, "Chemical composition of the essential oil and headspace solid phase microextraction of the guava fruits (Psidium guajava L)", Journal of essential Oil Research, 12 (2), 2000, pp: $153-158$

[17] Larlykova Iuv, Ivanova SM, Labetskala OI, "Effect of uvradiation on metabolism and structural - functional status of the rats erytrocyt membranes", Anakosm Ekolog Med Vol 39 No.2, 2005. 